\title{
Exploring Engagement in Tasks in the Language Classroom
}

\author{
JENEFER PHILP \\ Lancaster University \\ j.philp@lancaster.ac.uk \\ SusAn DuCHESNE \\ University of Wollongong \\ sued@uow.edu.au
}

\section{A BS T R ACT}

This article explores how learners engage in tasks in the context of language classrooms. We describe engagement as a multidimensional construct that includes cognitive, behavioral, social, and emotional dimensions of engagement among second and foreign language learners in the classroom. We discuss key concepts and indicators of engagement in current research on task-based interaction and outline some of the issues in researching engagement in this context.

\section{INTRODUCTION}

Any teacher observing his or her students in the classroom is aware of differences between them in terms of their interest and involvement. One pair might be completely off-task, whispering about the weekend, while another group might be compliant, yet paying little attention. A third pair might be hunched over pieces of paper, scribbling down ideas, asking one another questions, intent on working out the problem. It is clear from these brief examples that some student activity is more effective for learning than others. Van den Branden (this volume), for example, reminds us of the crucial part played by the teacher in motivating students through well-designed tasks that are both challenging and closely matched to their needs. Van den Branden recognized the need to involve students through tasks that are highly relevant and achievable with support, and that inspire effort and persistence. Engagement is the term frequently employed to talk broadly about learners' interest and participation in an activity. To date, however, in applied linguistics research there is little principled understanding of this overused term although there is a shared intuitive recognition of "engagement" as optimal for learning. The aim of this review article is to clarify what is meant by the term engagement with regard to task-based interaction among language learners. Our application is exclusive to the specific instructional setting of the classroom - the aims and learning goals particular to a given class and age group, the participants involved, and the learning activities. We begin with an overview of the construct and importance of engagement, based on educational research, and then focus on reviewing the term engagement in the specific setting of task-based interaction. 
In the field of educational psychology, the concept of engagement has been a topic of intensive study over the past decade. This robust research is embodied in a recent handbook of research in student engagement (Christenson, Reschly, \& Wylie, 2012), and in a theoretical review of the construct (Lawson \& Lawson, 2013). The research on engagement covers a broad spectrum of four contexts that are hierarchical: school, community, classrooms, and learning activity (see Skinner \& Pitzer, 2012). Due to the varied research contexts and foci, definitions of engagement are highly variable, with a lack of consensus in the literature (Reschly \& Christenson, 2012). In each context, different aspects of engagement are highlighted as important to the particular outcomes sought at this level. For example, the original research on engagement related to the level of school (e.g., Finn, 1989) and regarded students' participation or involvement as well as their sense of belonging in school. Outcomes were measured in dropout or retention rates. In contrast, at the level of activity, engagement concerns involvement in a specific activity or task in class and the outcome sought is learning. In foreign (FL) or second language (L2) settings, outcomes sought relate to language use and/or development. We use the term task here in a specific sense. Following R. Ellis (2009, p. 223) task refers to a particular kind of activity that involves a primary focus on meaning. Typically, tasks require the use of participants' own resources (e.g., their own language, their own ideas), and there is a clearly defined outcome (i.e., achievement of a nonlinguistic goal).

\section{The Nature and Importance of Engagement}

While implicit learning is recognized as constituting the major part of language acquisition, conscious mental involvement has also long been recognized as essential to efficient learning of novel material (N. C. Ellis, 2015). Paying attention is important, whether one is trying to understand something unfamiliar or complex, problem-solve, or learn a different way of doing something (Baars, 1997). Researchers of L2 acquisition have emphasized the need for L2 learners to pay attention to the connections between language form and its meanings in use (e.g., Gass, 2003; Leow, 2015; Long, 1996; Schmidt, 2001). This research has tended to focus on the construct of noticing, differentiating between noticing at the level of detection, awareness, and understanding (Leow, 2015; Robinson, 1995). Previous research recognizes gradations of cognitive involvement, and teachers and researchers alike use the word "engagement" as a near synonym. However, as we will see here, paying attention is just one dimension of engagement.

Engagement refers to a state of heightened attention and involvement, in which participation is reflected not only in the cognitive dimension, but in social, behavioral, and affective dimensions as well. A seminal article on school engagement by Fredricks, Blumenfeld, and Paris (2004) described engagement as a "multifaceted" or "multidimensional" construct that includes, at the least, three components: cognitive, behavioral, and emotional. In applied linguistics, each of these and other 
dimensions are recognized as important to instructed language learning (e.g., regarding affect: Schumann, 1997; Swain, 2013; regarding social factors, see Philp \& Duchesne, 2008), yet, each tends to be considered in isolation. Increasingly, researchers acknowledge the need to take account of the interdependence of these different facets of human experience (e.g., Larsen-Freeman \& Cameron, 2008). In the education literature, these multiple dimensions are demonstrated to be overlapping and interdependent, not isolated independent constructs (Christenson et al., 2012). For example, when people are involved in a learning activity, experience is more memorable when affective states are also aroused (McGaugh, 2013; Pekrun \& Linnenbrink-Garcia, 2012; Weiss, 2000). In contrast, the student who is bored or disinterested in a task is emotionally disengaged. Similarly, someone who is disconnected with other group members, and thus socially disengaged, may also be behaviorally off-task: not listening to responses of other members, not contributing to the interaction. They are unlikely to invest effort or persistence, or to direct attentional resources in effective ways to be cognitively engaged or even to fully complete the task (i.e., to be behaviorally engaged). Analysis of engagement allows us to include an emphasis both on attention (the cognitive dimension) and on the affective, behavioral, and social dimensions that support effective learning.

Christenson et al. (2012) underscored the crucial role of engagement for learning: "Student engagement drives learning; it requires energy and effort; is affected by multiple contextual influences; and can be achieved for all learners."(p. 817; see also Gettinger \& Ball, 2007). If we can understand engagement better, we are better equipped for investigating how to engage all learners. Engagement is a construct closely related to motivation. Indeed, it is described by some as the visible manifestation or "descriptor" of motivation (Ainley, 2012; Cleary \& Zimmerman, 2012; Martin, 2012; Reeve, 2012; Schunk \& Miller, 2002) and by others as the precursor of motivation (Pekrun \& Linnenbrink-Garcia, 2012). Anderman and Patrick (2012) suggested that for this reason it needs to be explored through context-specific research, through observation of students in action, that is, in the classroom context, actually working on tasks in class. Detailed discussion of the relationship between motivation and engagement is outside the scope of this article. We note here, however, that it is a close and complex relationship (for further discussion, see Reschly \& Christenson, 2012).

\section{The Construct of Engagement}

Descriptions of engagement tend to foreground characteristics such as interest, effort, concentration, active participation, and emotional responsiveness. That is, engaged students are not just going through the motions; they expend focused energy and attention, and they are emotionally involved. For example, Skinner and Pitzer (2012) characterized engagement as "constructive, enthusiastic, willing, emotionally positive and cognitively focused participation with learning activities in school" (p. 22). The interdependence of the dimensions of engagement is a vital characteristic of the construct. Before we discuss this interdependence in greater detail, we will first identify the salient characteristics of each dimension in turn. 


\section{Cognitive Engagement}

Cognitive engagement involves processes such as sustained attention and mental effort (Helme \& Clarke, 2001), often including self-regulation strategies. Helme and Clarke (2001) identified a range of indicators of cognitive engagement in collaborative activities, including questioning; completing peer utterances; exchanging ideas; making evaluative comments; giving directions, explanations, or information; justifying an argument; and making gestures and facial expressions. Further indicators of cognitive engagement could include private speech and exploratory talk (see Barnes, 2008; Mercer \& Dawes, 2008). Evidence may come from audio and visual data, lesson transcripts, and observations, or indirectly through retrospective questionnaires and interviews such as stimulated recall (see Gass \& Mackey, 2014), carried out postlesson.

An illustration of cognitive engagement identified via retrospective interviews comes from a study by Early and Marshall (2008) of a high school English class in Canada. These adolescent students, with English as an additional language (EAL), worked in groups to visually portray the meaning of a short story. The teachers and researchers found that having to personally express the key ideas of the story using multimodal devices enhanced the students' level of involvement with the text, both behaviorally (through multiple readings and discussions) and cognitively (understanding, looking deeper). In the following excerpt from an interview, one student commented:

\section{Example 1}

You know, instead of saying it helped us understand, it is more a matter of it forced us to understand $\ldots$ because we need to read it and read it and read it again, so we can come up with the symbols ... so it is more a matter of it forced us to understand, instead of helped us to understand ... you can't do this if you don't look at things deeper. (Early \& Marshall, 2008, p. 386)

Cognitive engagement can be demonstrated by phrases such as "I think," by causal connectives such as "because," and by questions. There may also be evidence of argument or disagreement that reflects reasoning or exemplification. In Example 2, from Gibbons (1991), two primary school boys with EAL are involved in the task of designing a platypus enclosure for a zoo. Their cognitive engagement with this task is seen in the exploratory nature of their suggestions (Barnes \& Todd, 1995; Mercer, 1995). It is also reflected in pauses, hesitations, reformulation, and repetition (lines 1-3). They build on one another's suggestions, each responding with new ideas and giving reasons (lines $4,5,6$ ).

Example 2

1 Joseph: So ... if we have a sign that says ... if you find a platypus take it ... take him to ... a ... no ... a staff member. 
2 Patrick: No, no ... don't touch it ... please don't touch ... yes yes that's what we'll do ... we'll put ... please don't ... no ... please don't touch platypus spine.

3 Joseph: No ... what is it? ... what is it? ... it's got something that's poisonous.

4 Patrick: So that'll make the people walk away ... because they aren't going to take it home if it's got something poisonous on it.

5 Joseph: Please ... please don't touch the platypus because it has ... a poisonous spur.

6 Patrick: Yes ... please do not touch the platypus because of its spur ... its spur is dangerous and you will have to be taken to hospital ... right? (Gibbons, 1991, pp. 27-28)

Whereas this example involves a focus on content, in Example 3, among adolescent foreign language learners of Spanish (Toth, Wagner, \& Moranski, 2013) the focus of engagement is on language itself as the students try to work out the underlying rules governing the use of inchoative $s e$ in a report of an earthquake and storm in Spanish.

\section{Example 3}

1 Alberto: If the direct object is itself you would use, you would use se

2 Jose: Well it's, eh, like the same thing as last time. When the verb is eh defined or like, its-ah, what's the word-I'm drawin' a blank here, Alberto...specified there we go.

3 Alberto: Eh, yeah

4 Jose: When the verb is specified it follows the verb but when it's not it like follows the direct object again

5 Alberto: Sounds good. (Toth et al., 2013, p. 294)

Each of these examples indicates concentrated effort from the participants as they think about something they need to solve: how to use symbols, images, and words to synthesize a story (Example 1); what should go in a platypus enclosure (Example 2); and how to explain the underlying rule for use of a particular linguistic form (Example 3).

Of course, cognitive engagement is not only manifested in verbal form but also may be seen in facial expressions and body positioning, although verbalization of thought processes allows it to be more evident to the observer. Besides qualitative data sources, there are also quantitative research instruments that investigate engagement. Two examples of survey instruments created to explore engagement at the level of school use Likert scales and include items relevant to cognitive engagement at the class level. In the High School Survey of Student Engagement, (http://ceep.indiana.edu/hssse ), Yazzie-Mintz and McCormick (2012, p. 750) included questions about U.S. students' effort, investment in work, and learning strategies. Darr (2012, p. 713), described a survey for New Zealand schools to investigate students' self-perception of engagement. It includes items such as 
"I pay attention in class," "I find it easy to concentrate on what I am doing in class," and "I take notice of the comments my teacher makes about my work."

\section{Behavioral Engagement}

Behavioral engagement is typically described simply in terms of time on task or participation. Thus being "on-task" is synonymous with behavioral engagement. Gettinger and Walter (2012), based on research in U.S. schools, claimed that "academic engaged time," that is, the amount of time students are actively involved, predicts academic achievement, and engagement is directly related to learning outcomes (see also Fredricks et al., 2004). Similarly, in earlier SLA research, measures of engagement involving word counts (Bygate \& Samuda, 2009) and turn counts (Dörnyei \& Kormos, 2000) are measures of behavioral engagement (time on task), without capturing other dimensions (e.g., cognitive, social, or emotional engagement).

In the following examples (unpublished data from Oliver, Philp, \& Mackey, 2008), two pairs of young children (ages 5-7) with EAL work on the same task to identify and count specific shapes in a picture. In Example 4, the pair is on-task behaviorally, focused on doing the task-they take turns identifying shapes in the picture and tally the numbers for their handout. In Example 5, Learner $G$ is drifting off task and amusing himself with silly answers, to the frustration of the partner who remains on task.

Example 4

1. O: I call this one, I already know this one I already know this one

2. R: These are not triangles.

3. O: 16 this one 16

4. R: 16 [rising intonation]

5. O: OK and this and triangle, do you see other triangle?

6. R: No that's a rectangle. What is that number?

Example 5

1. D: Hey $\mathrm{xx}$ xx my turn=

2. G: Thank you Mr. $x x$

3. D: How many square = how many square did you find?

4. G: A billion

5. D: No... stop laughing

Some researchers (Anderson, 1975) perceive behavioral engagement as a dichotomy: engaged (i.e., often synonymous with on-task behavior) or disengaged (i.e., associated with off-task behavior). Others (Finn \& Zimmer, 2012; Mahatmya, Lohman, Matjasko, \& Feldman Farb, 2012) consider behavioral engagement a continuum, depending on degree and quality of participation, using amount of effort, persistence, and active involvement as indicators of this. These indicators 
broaden the understanding of what constitutes behavioral engagement, and they help to provide theoretical explanations of links to learning and to other dimensions of engagement. Behavioral engagement has been measured qualitatively via observation of participation and effort as well as teacher reports and student selfreports or interviews (see Fredricks \& McColskey, 2012). In task-based studies, indicators tend to focus on academic behaviors such as answering questions or participating in tasks. Quantitative measures of task engagement may include items in survey instruments relating to participation and effort, for example, "I take care that my homework is done properly" (Darr, 2012, p. 713). Other examples of items include "When I am in class, I just act like I am working" (a reversed item) and, for persistence, "If I have trouble understanding a problem, I go over it again until I understand it" (Fredricks \& McColskey, 2012, p. 770). An example of an item on effort is, "I take care that my homework is done properly" (Darr, 2012, p. 713).

\section{Emotional Engagement}

The construct of emotional engagement is defined variously according to the research focus. For example, concerning school engagement, Yazzie-Mintz (2009) described emotional engagement as "students' feelings of connection to (or disconnection from) their school-how students feel about where they are in school, the ways and workings of the school, and the people within their school" (p. 16).

In relation to the context of the class and the task, Skinner, Kindermann, and Furrer (2009) defined emotional engagement as motivated involvement during learning activities, and they identified enthusiasm, interest, and enjoyment as key indicators of emotional engagement, and at the other end of the scale, anxiety, frustration, and boredom as indicators of negative emotional engagement (disaffection). Baralt, Gurzynski-Weiss, and Kim (2016) added purposefulness and autonomy as aspects of emotional engagement. Emotional engagement may also include students' feelings of connection or disconnection with their peers in the class and, particularly, their task interlocutors. For example, Early and Marshall (2008) noted the positive benefits of group work for the students in the class: "For the most part, working in groups also had a strong affective component and facilitated the students' investment in the task" (p. 388). Students were eager to talk about their task, and did so outside of class time, enjoying the social benefits of having a common interest and purpose. As one student said:

It was great to show up and know that I have conversations with friends. We talked about the project the whole time. Sometimes I would think of an answer of something I didn't know in class. I would ask them right away. It is funny ... projects aren't usually like that. (Early and Marshall, 2008, p. 388)

This last quote reflects interdependence between the dimensions of engagement: The student spends extra time on the task, out of cognitive interest (finding an answer) and for the pleasure of sharing a conversation with friends. Here, social engagement during group work is supported through positive encouragement and 
active listening from peers. Conversely, learners may be disheartened by peer exclusion, resulting in negative emotions and lack of engagement. This is reflected in a study by Baralt et al. (2016) among young adult learners of FL Spanish. As seen here, one student's frustration at exclusion by her partner in an online chat session resulted in deliberate disengagement:

To be honest I hated this task. I didn't really know the person I was chatting with, and I don't think he really cared about working with me. He just wanted to get the task done and didn't really talk to me at all (...) I tried but he just kept going so finally I just let him retell the story and mentally checked out. (Baralt et al., 2016, p. 233)

We see from these examples that emotional engagement relates to motivation and refers to the affective nature of learners' involvement. Emotions, whether positive (e.g., interest, enjoyment) or negative (e.g., boredom, frustration), influence effort and strategies for learning. The interdependent nature of dimensions is evident here: The emotional dimension links behavioral, social, and cognitive facets, as Pekrun and Linnenbrink-Garcia (2012) argued. They conceived of emotions as intrinsic to rather than as a facet of engagement, describing emotions as either activating or deactivating of engagement.

\section{Social Engagement}

While not included in all models of engagement, we believe that in the context of instructed language learning, the social dimension to interaction should be foregrounded as a dimension of engagement (see also Svalberg, 2009). Social engagement is closely linked to emotional engagement, particularly among child and adolescent learners where affiliation is a powerful social goal (Philp \& Duchesne, 2008), at a period when peers provide a unique context for learning (Hartup, 1992). In recent research on interaction, particularly from a sociocultural perspective, there has been a new emphasis on collaboration between peers working on tasks together. Storch's (2002) model of patterns of interaction, based on Damon and Phelps (1989), has been particularly influential here because it draws attention to mutuality in particular as impacting on success of task-based interaction between peers.

Following Storch (2002), a growing number of researchers (Moranski \& Toth, 2016; Sato \& Ballinger, 2012; Storch, 2008; Toth et al., 2013) have suggested that learners are likely to be more effective in language learning when they are socially engaged: that is, when they listen to one another, draw from one another's expertise and ideas, and provide feedback to one another. Cognitive, social, and behavioral dimensions of engagement are evident in Example 6, from Moranski and Toth (2016, p. 306). This pair of adolescent learners varies in knowledge of Spanish as a foreign language, but benefits from one another's expertise as they discuss form-meaning connections for se and $m e$. The mutuality between them is evidenced by the reciprocity in their discussion: each building on the other's turn. In Example 6, Raquel ${ }^{1}$ asks many questions, which Diego has to think about 
and explain (lines 10-24, 36-39). In turn, Raquel argues the point on a form she identifies as reflexive (lines 13-21).

Example 6

\begin{tabular}{|c|c|c|}
\hline $10-12$ & Diego: & $\begin{array}{l}\text { This is like, stuff that's like, basically this is kind of indirect. } \\
\text { So like things happen to her. }\end{array}$ \\
\hline 13 & Raquel: & Yeah that's what [reflexive \\
\hline 14 & Diego: & umm] \\
\hline 15 & Raquel: & $=$ is. Something that you do to yourself. \\
\hline 16 & Diego: & No that's not re (.) [no \\
\hline 17 & Raquel: & That's] the [things with the SE ME = \\
\hline 18 & Diego: & Well kind of] \\
\hline 19 & Raquel: & $=$ at the ends. \\
\hline 20 & Diego: & Yeah. \\
\hline 21 & Raquel: & Yeah $\uparrow$ Which is reflexive, right? $\uparrow$ \\
\hline $22-24$ & Diego: & $\begin{array}{l}\text { Well it's just (.) member, you know, it's kind of like indirect } \\
\text { where it's (.)(they) did it to her like }\end{array}$ \\
\hline [8 turns later] & & \\
\hline $36-37$ & Raquel: & Why's it "me sentaron"? It doesn't it [mean Ustedes (form)? \\
\hline $38-39$ & Diego: & $\begin{array}{l}\text { Cuz they sat her down.] And she was saying it (.) like they did } \\
\text { it to me. }\end{array}$ \\
\hline
\end{tabular}

In Example 7 (Philp \& Duchesne, 2008, p. 96), from a classroom study of a kindergarten child (Yessara) using EAL with her peers, we see social engagement among three young children in a kindergarten class. While writing out identical lunch orders at school, they mimic one another both in speech and in action. Such reciprocity and mutuality reflects learners' social engagement with one another.

\section{Example 7}

5. B Yessara are you lunch ordering?

6. Y yes

7. B oh all three of us are! [delighted]

8. Y Yessara my name is [single contour]

9. $\mathrm{R}$ Roberta my name is [copying] too and chicken nugget

10. $\mathrm{Y}$ chicken=

11. $\mathrm{B}=$ two chicken nuggets

\section{The Importance of Context in Defining Engagement}

One contributing factor in the multiple definitions of engagement has been the wide range of contexts to which it is applied. Janosz (2012) argued that understanding how engagement is expressed differently in various contexts is important to understanding its determinants and outcomes in those contexts. This perhaps underscores how the facets of engagement are conceived differently according to the underlying theoretical position, and the setting of the research. Reschly and Christenson (2012) suggested that this is reflected inevitably by the "jingle" (same term used to describe different things) and the "jangle" (same construct described 
using different terms) of engagement research. In this article, we limit our context to task-based interaction in the language classroom, with variation expected also according to age and classroom setting (including mode, e.g., computer-mediated or face-to-face; individual, teacher-fronted, or peer interaction with the task; and instructional focus).

Focusing on task engagement, we argue that what counts in engagement in a language classroom will be specific to the learning goals and processes of language learning. For example, in recent second language acquisition (SLA) research on engagement, it is language-related episodes (Swain \& Lapkin, 2001) that are the predominant means of operationalizing engagement because of the importance placed on learners' focus on language form, meaning, and use. Social engagement is another aspect that is particularly important to language learning, given the opportunities that social interaction offers for language practice. The particular processes by which this facet of engagement is linked to learning outcomes are different from those that link it to learning in mathematics, for example, where social interaction may provide opportunities to be exposed to other ways of thinking about a problem and to elaborate thinking (Webb, 2013). The processes that are the focus of research will also affect the indicators of each of the dimensions. Research conducted in mainstream classrooms has already found different sets of indicators of cognitive engagement for different curriculum areas including mathematics (Helme \& Clarke, 2001) and reading (Guthrie, Wigfield, \& You, 2012). Storch (2008) has identified a set appropriate to the language learning context, which we discuss in the section on "Engagement in Task-Based Interaction."

\section{Considering Engagement as a Multidimensional Construct}

The multidimensional and interdependent nature of components of engagement is seen, for example, in group work, where the participants may be so focused on the procedural aspects of the task (behavioral engagement) that they are not involved cognitively; they approach it in a surface manner, without really trying to understand it (O'Donnell, 2006). Similarly, as seen in Example 5, excitement when working together in a task involving group work (social and emotional engagement) may interfere with or distract learners from cognitive and behavioral engagement. In some situations, the same dimension supports engagement in other dimensions. For example, we saw in the excerpt from Early and Marshall (2008) the power of social engagement in group work to awaken emotional, cognitive, and behavioral engagement. Table 1 provides examples of some of the ways in which each dimension can mediate other dimensions of engagement, either positively or negatively. The concept of "flow" (Csikszentmihalyi, 1990)—or the allencompassing involvement of the individual to the exclusion of all else-suggests the ultimate in engagement, where all facets are positively involved. It is also possible for the dimensions to compete with or negatively influence one another, as is further explored below.

The multidimensional, interdependent character of engagement described above has a number of implications for research. First, it suggests that a focus on 
TABLE 1. Mediating Effects of Dimensions of Engagement

\begin{tabular}{|c|c|c|c|}
\hline $\begin{array}{l}\text { Dimension of } \\
\text { Engagement }\end{array}$ & $\begin{array}{l}\text { Mediating Effect } \\
\text { on Other } \\
\text { Dimensions }\end{array}$ & $\begin{array}{l}\text { Activating or } \\
\text { Strengthening } \\
\text { Engagement }\end{array}$ & $\begin{array}{l}\text { Deactivating } \\
\text { or Inhibiting } \\
\text { Engagement }\end{array}$ \\
\hline \multirow[t]{3}{*}{ Behavioral } & Cognitive & $\begin{array}{l}\text { Task itself focuses attention, } \\
\text { prompts deep thinking. }\end{array}$ & $\begin{array}{l}\text { Focused on task completion } \\
\text { at a superficial level: } \\
\text { surface approach to } \\
\text { learning limits cognitive } \\
\text { engagement. }\end{array}$ \\
\hline & Emotional & $\begin{array}{l}\text { Successful task completion } \\
\text { prompts student to want } \\
\text { to do more. }\end{array}$ & $\begin{array}{l}\text { Task is boring or frustrating } \\
\text { to complete, so student } \\
\text { approaches this kind of } \\
\text { activity negatively in } \\
\text { future. }\end{array}$ \\
\hline & Social & $\begin{array}{l}\text { Cooperative tasks } \\
\text { strengthen social links. }\end{array}$ & $\begin{array}{l}\text { Competitive tasks may } \\
\text { disrupt social relations. }\end{array}$ \\
\hline \multirow[t]{3}{*}{ Cognitive } & Behavioral & $\begin{array}{l}\text { Students are intent on } \\
\text { "solving the puzzle" and } \\
\text { keep working until it is } \\
\text { done. }\end{array}$ & $\begin{array}{l}\text { Students are so focused on } \\
\text { one aspect of a task that } \\
\text { they neglect others. }\end{array}$ \\
\hline & Emotional & $\begin{array}{l}\text { Student's interest is caught } \\
\text { by a particular idea or } \\
\text { cognitive challenge. }\end{array}$ & $\begin{array}{l}\text { Cognitive challenge results } \\
\text { in frustration. }\end{array}$ \\
\hline & Social & $\begin{array}{l}\text { Students are prompted to } \\
\text { work with or seek help } \\
\text { from others by the ideas } \\
\text { or challenges of the task. }\end{array}$ & $\begin{array}{l}\text { Student works on the task } \\
\text { individually and doesn't } \\
\text { want input from others. }\end{array}$ \\
\hline \multirow[t]{3}{*}{ Emotional } & Cognitive & $\begin{array}{l}\text { High interest in topic or task } \\
\text { prompts concentrated } \\
\text { thinking. }\end{array}$ & $\begin{array}{l}\text { Student is so excited that } \\
\text { she or he can't focus or so } \\
\text { anxious that she or he } \\
\text { can't think. }\end{array}$ \\
\hline & Behavioral & $\begin{array}{l}\text { Interest and excitement } \\
\text { prompt student to keep } \\
\text { working on the task in } \\
\text { spite of difficulties. }\end{array}$ & $\begin{array}{l}\text { Boredom or frustration } \\
\text { leads to no work on task. }\end{array}$ \\
\hline & Social & $\begin{array}{l}\text { One peer's excitement about } \\
\text { or interest in a task draws } \\
\text { others in. }\end{array}$ & $\begin{array}{l}\text { Mismatch of emotional } \\
\text { engagement leads to lack } \\
\text { of social connection } \\
\text { between peers on a task. }\end{array}$ \\
\hline \multirow[t]{3}{*}{ Social } & Cognitive & $\begin{array}{l}\text { Peers working together } \\
\text { support each other's } \\
\text { thinking (mutuality, } \\
\text { reciprocity). }\end{array}$ & $\begin{array}{l}\text { Student switches off from } \\
\text { task because his or her } \\
\text { partner isn't working } \\
\text { with the student; or peers } \\
\text { distract each other from } \\
\text { thinking about the task. }\end{array}$ \\
\hline & Emotional & $\begin{array}{l}\text { Student enjoys the task } \\
\text { because of the social } \\
\text { element. }\end{array}$ & $\begin{array}{l}\text { Student doesn't enjoy task } \\
\text { because social relations } \\
\text { aren't working. }\end{array}$ \\
\hline & Behavioral & $\begin{array}{l}\text { Student spends time on task } \\
\text { because of social aspect. }\end{array}$ & $\begin{array}{l}\text { Social goals are more } \\
\text { important than doing the } \\
\text { task. }\end{array}$ \\
\hline
\end{tabular}

one dimension, while useful, provides only a partial picture: We need to measure more than one dimension, if we are to capture the full complexity of engagement. Second, as Janosz (2012) argued, we need to spell out the relationships between the 
different dimensions of engagement and explore how each mediates and influences the effects of the others, through theory and research. There is a range of positions taken in the engagement literature about these relationships, and SLA researchers will need to theorize and investigate them in their own context. For example, Lam, Wong, Yang, and Liu (2012) argued that researchers should avoid overlapping of the engagement dimensions in their definitions, while Pekrun and LinnenbrinkGarcia (2012) described this as an aspect of the complex and multidimensional nature of the concept and described dimensions as inherently interdependent, for example, "cognitive-behavioral" or "social-behavioral." What is the evidence from task-based L2 research? Our examples (given above and in Table 1) suggest that the second is a more accurate picture, but the particular relationships between the dimensions may vary across contexts. At the level of task, how engagement manifests and how the different dimensions interrelate will vary in each context for differing age groups of students, in varying curricular contexts, with different patterns of participant interaction, and for different kinds of tasks. Studying these relationships within a particular context, such as task-based language learning, is important to illuminate the processes involved.

In Table 1, we provide examples of how each dimension may mediate the effect of other dimensions. We now focus specifically on engagement in task-based interaction.

\section{Engagement in Task-Based Interaction}

Different facets of engagement are recognized in SLA literature, but to date, the construct itself is rarely conceptualized or operationalized, and exceptions tend to be limited to capturing a single dimension of engagement. As noted above, earlier work in SLA on engagement at the class level depended largely on gross measures of quantity of talk among learners (Bygate \& Samuda, 2009; Dörnyei $\&$ Kormos, 2000). However, this captured only aspects of behavioral engagement. With regard to engagement with language specifically, Storch (2008) identified instances in which peers talk about language use or provide correction. These language-related episodes (LREs) (Kowal \& Swain, 1994) have been adopted as the primary unit of analysis for engagement in much of more recent work (e.g., Baralt et al., 2016; Dobao, 2016; García Mayo \& Azkarai, 2016; Svalberg, 2012). Storch used LREs to examine the extent to which participants notice features of language while reconstructing a written text. Storch differentiated between "limited" and "elaborate" engagement in describing learners' metatalk. The latter describes how learners "deliberated over the language items, sought and provided confirmation and explanations, and alternatives" (Storch, 2008, p. 100). Thus, in Storch's model, engagement is limited to cognitive engagement with language.

However, consistent with an understanding of learning as involving social, affective, cognitive, and behavioral influences, we argue that it is essential to recognize engagement as more than unidimensional. Research drawing on a wide range of theorists, including Lewin, Vygotsky, Bandura, and Bronfenbrenner, has clearly demonstrated the interaction of the social, emotional, cognitive, and behavioral 
domains in learning and development (e.g., Adolph \& Berger, 2011; Geeslin \& Long, 2014; Lantolf, 2012; Larsen-Freeman, 2014; S. Mercer, 2011; Pekrun, Goetz, Titz, \& Perry, 2002; Posner \& Rothbart, 2000). Just as in learning and development, then, in engagement as well, these domains interact with one another to shape human experience, as we have seen.

Svalberg (2009; see also Svalberg, 2012) is one of the few applied linguists to date to recognize a complexity beyond cognitive or behavioral engagement alone. Svalberg's suggested model of "engagement with language" does not make reference to behavior, but it does incorporate the possibility of cognitive, social, and affective facets, noting that "in addition to its cognitive aspects [engagement with language] crucially involves a range of social and affective phenomena" (Svalberg, 2009 , p. 243). While she does not specify engagement as multidimensional (as did Fredricks et al., 2004), Svalberg clearly acknowledges interdependence between social, cognitive, and affective states. Her identification of these multiple aspects of engagement is a critical step forward in understanding engagement in language learning contexts, because it recognizes the complexity of attention, learning, and development, as well as the many factors that mediate how students perceive, interpret, and engage with what happens in the classroom and beyond.

Some researchers recognize complexity by foregrounding agency as a central component, as seen in some educational research. For example, drawing on selfdetermination theory (e.g., Deci \& Ryan, 1985), Reeve (2012) included agency as an interrelated facet of engagement, alongside behavioral, emotional, and cognitive facets (see also Michell, 2012). Reeve described agentive engagement as the learner's "proactive, intentional and constructive contribution into the flow of the learning activity" (p. 151). For instance, Reeve recognized agency in the student's own input, participation, and suggestions - "enriching the learning activity" rather than "passively receiving" (p. 153). This work is useful with regard to taskbased interaction in that indicators are tied to the active, observable contribution of the learner interacting with other learners (or with the teacher in whole-class interaction). Svalberg's (2009) description of engagement with language aligns with this description. Svalberg foregrounded the agency of the learner when she identified the learner as "interactive and initiating" (socially engaged); and/or as one who "pays focused attention and constructs their own knowledge" (cognitively engaged); and /or one who has "a positive, purposeful, willing and autonomous disposition towards the object (affectively engaged)" (p. 247).

\section{Examples of Indicators of Engagement in Task-Based Interaction Research}

In this section, we illustrate the different ways in which engagement, as a multidimensional construct, is identified with reference to two recent studies involving task interaction. Based on Svalberg's (2012) model, the work of Baralt et al. (2016) qualitatively compared engagement of 40 adult learners in a North American university, learning Spanish as a foreign language during task-based interaction under one of two conditions: (a) in a face-to-face classroom setting or (b) through 
TABLE 2. Coding Scheme (adapted from Baralt et al., 2016, pp. 222)

\begin{tabular}{|c|c|c|c|}
\hline Dimension & Evidence & Sample & Data source \\
\hline Cognitive & $\begin{array}{l}\text { Noticing of language } \\
\text { and/or interaction } \\
\text { features? } \\
\text { Attention on language } \\
\text { as object or language } \\
\text { as medium? } \\
\text { Critical or analytic } \\
\text { reflection during the } \\
\text { task? } \\
\text { (Reasoning induction } \\
\text { or memory/imitation- } \\
\text { based reflection?) } \\
\text { Hypothesis } \\
\text { formation? }\end{array}$ & $\begin{array}{l}\text { LRE : noticing the form of } \\
\text { "dormía" } \\
\text { Face-to-face interaction } \\
\text { (p. 23) } \\
\text { A: Sí pero Luís dormió (Yes } \\
\text { but Luis slept) } \\
\text { B: I think durmió isn't that } \\
\text { like irregular? } \\
\text { A: Or wait maybe it should } \\
\text { be imperfect? } \\
\text { B: Aaaahh sí sí sí acción en } \\
\text { progreso (Aaaaahh yes yes } \\
\text { yes action in progress) } \\
\text { A: Entonces Luís dormir } \\
\text {...dormía... dormía. (So } \\
\text { Luis to sleep ... was } \\
\text { sleeping ... was sleeping) }\end{array}$ & Transcript or chat log \\
\hline Affective & $\begin{array}{l}\text { Willingness to engage? } \\
\text { Eagerness or } \\
\text { withdrawal? } \\
\text { Learner's } \\
\text { purposefulness } \\
\text { (Focused on task or } \\
\text { bored?) }\end{array}$ & $\begin{array}{l}\text { Overheard or observed by } \\
\text { researcher/teacher (p. 29): } \\
\text { Encouraging comments: } \\
\text { "muy bien!," “yes!" “good } \\
\text { job," high fives }\end{array}$ & $\begin{array}{l}\text { Questionnaire, } \\
\text { Teacher comments, } \\
\text { Transcript } \\
\text { chat log }\end{array}$ \\
\hline Social & $\begin{array}{l}\text { How interactive with } \\
\text { partner to learn? } \\
\text { Socially supportive? } \\
\text { Negotiates and } \\
\text { scaffolds? } \\
\text { Leader or follower? } \\
\text { (Reactive or initiating } \\
\text { types of interactions?) }\end{array}$ & $\begin{array}{l}\text { LREs including scaffolding } \\
\text { Social conversation (p. 30) } \\
\text { 1. Learner J: ...but yeah it } \\
\text { was really fun! You should } \\
\text { come out with us next time! } \\
\text { 2. Learner I: I'd love to. You } \\
\text { know what else- }\end{array}$ & \\
\hline
\end{tabular}

synchronous computer-mediated communication. The task involved story retelling, using a comic strip as the prompt, and differed in complexity according to whether information about the character's motives was provided (thought bubble included) or divined (empty speech bubble). Data comprised transcriptions, chat logs, and questionnaires. Consistent with Svalberg (2012), Baralt et al. described engagement as a cognitive and/or affective and/or social state, and identified these through a range of indicators developed from the data. Transcripts of group work interaction together with a posttask questionnaire were coded for evidence of cognitive, social, and affective engagement.

Baralt et al.'s (2016) coding of the data was based primarily on instances of LREs. This is illustrated in Table 2. For cognitive engagement, they identified noticing and reflection on language form. Affective engagement related to learners' attitudes, willingness to interact, their purposefulness (orientation), and their autonomy (pp. 222, 227). This differs from the conception of emotional engagement in the education literature. Social engagement related to aspects of mutual- 
ity and reciprocity, which Baralt et al. described in terms of interactiveness and supportiveness, as well as relational indicators of friendship, trust, and inclusion (p. 229).

Perhaps symptomatic of the interdependence between dimensions of engagement, categories often overlapped. For example, learner scaffolding (or lack of support thereof) was coded as social engagement-yet this could also constitute an LRE, an indicator of cognitive engagement.

The self-report questionnaire helped to illuminate learners' perceptions of the interaction, and reflected varied engagement. Eight questions elicited statements about overall perception of the task, goal of the task, noticing of any specific language features, opinion as to usefulness of working with the partner, helpfulness of the partner, and the students' relative willingness to contribute as a pair. It also elicited adjectives to describe the task and their feelings about the task.

In Example 8, one student's reflection provides evidence of both cognitive ${ }^{(\mathrm{COG})}$ and social engagement ${ }^{(\mathrm{SOC})}$ (Baralt et al., 2016, pp. 227, coding added).

\section{Example 8}

a good challenge $\mathrm{e}^{(\mathrm{COG})}$, I want more tasks like this to make me really think ${ }^{(\mathrm{COG})}$, I had to work hard ${ }^{(\mathrm{COG})}$ but my partner helped $\mathrm{me}^{(\mathrm{SOC})}$, this task pushed me to really use Spanish like I never have before.

Other responses reflect the emotional dimension of engagement, as seen in Example 9 (Baralt et al., 2016, unpublished data, and p. 228, respectively, coding added). One student's experience was framed very positively, suggesting a willingness to participate, positive attitudes and motivation; and for another it was negative.

\section{Example 9}

S1 We both just really saw it as a challenge ${ }^{(\mathrm{COG})}$ and it was new and fun ${ }^{(\mathrm{EMOT})}$. My partner's determination really motivated $\mathrm{me}^{(\mathrm{SOC})}$

S2 No, I don't think my partner and I were both equally willing to contribute $^{\mathrm{NEG}-\mathrm{SOC} / \mathrm{NEG}-\mathrm{COG}}$ in retelling the story. This experience felt like tension $^{(\mathrm{NEG}-\mathrm{SOC})}$ in a quiet room.

The social dimension of engagement highlights social relations between learners as an important variable in task outcomes, something that often remains hidden in studies of task-based interaction because it is not considered.

Another study of task-based interaction compared engagement in dyadic narrative and opinion gap oral tasks, among 32 adult learners of English in Japan. For logistical reasons, Lambert and Philp (2015) identified engagement based only on audio recordings and transcriptions of their pair work. Based on educational research (Christenson et al., 2012), Lambert and Philp described engagement as a multidimensional construct involving cognitive, behavioral, and social-emotional facets. Like Baralt et al. (2016), indicators of engagement were developed from the interaction data, resulting in some variation according to task type. For 
example, in the narrative task, the participants' responsiveness and attentive listening are reflected both through questions and negotiation of meaning (cognitive engagement) and by back channeling, commentary, and expressions of empathy (social/emotional engagement). In the opinion task, indicators of engagement included provision of reasoning, offering opinions, or acknowledging the interlocutor's opinion. Here "opting out" (e.g., by giving no response or saying "I don't know") was an indication of low or no engagement.

In the narrative task, one participant was instructed to recount an interesting story that had happened to him or her personally. Although ostensibly a monologue, in most cases this was carried out dialogically, reflecting the engagement of both participants. In Example 10, the storyteller (S) talks about problems at the airport in Thailand when returning from Myanmar. Both questions and negotiation of meaning indicate cognitive engagement in this example, as the two participants work to understand one another (lines 1-8). In the opinion gap task, indicators of cognitive engagement included questions, reasoning, and suggestions, as well as negotiation of meaning. As seen in lines 9-11 of Example 10, social engagement is reflected in an extended closure to the story, and by empathy of the interlocutor (line 15), as she imagines the potential problems that might have ensued.

Example 10

1. I Yes. Was she a Japanese woman? FOLLOW UP QUESTION

2. S No, she's Thailand. She's Thailand (.) person. So, she can speak Thailand and Japanese.

3. I Oh, that's good.

4. S Yes. Yeah, yeah, that's good. So she can translate and interpret the language. Both of them. Yeah, yeah, yeah, like that.

5. I How How she tol told a staffs of the airport? ${ }^{\text {NEG -SOC }}$

6. S Sorry, how? ${ }^{\text {CLARIFICATION REQUEST }}$

7. I What how How she help your problem? MODIFIED OUTPUT $^{\text {I }}$

8. S Ah, actually, she's also custom staff between between Thailand and between Thailand and Myanmar.

9. I Yes.

10. S Actually, she was a staff (.) of the custom.

11. I Ah.

12. S So she helped me. Yeah, yeah. EXTENDED CLOSURE

13. I That was good.

14. S Yeah, yeah, good (.) fortune.

15. I If If you hadn't (known) (.) know her... ${ }^{\text {EMPATHY }}$

16. S Yeah.

17. I You wouldn't be here.

18. S Yeah, yeah, I wouldn't be here. So, it's good. Okay. (Lambert \& Philp, 2015)

Example 11 involves a different pair of students performing the same narrative task as Example 10. It further illustrates coding for indicators of social and emotional 
engagement. In this case, the story, told by a female first-year student, involves illness related to stress and homesickness. Her interlocutor (FI), an older female student, empathizes with the speaker's problem, saying "I know how you feel" and "I was just like you," and provides advice and encouragement.

\section{Example 11}

FS But I when when I go back to my apa= apart, and then I I felt loneliness.

FI I know. I know how you feel. I have= I know. ${ }^{\text {EMPATHY }}$

FS But but but gradually I I am use using to.

FI Good. ${ }^{\text {EVALUATIIVE COMMENT }}$

FS This life...

FI Yeah, it takes time. You'll be fine. 'Cause, I like really like you. I was just like you, but you know, things are going to get better. ${ }^{\text {EMPATHY/AFFILIATION }}$ (Lambert \& Philp, 2015)

\section{Implications for Measures of Engagement in Task-Based Interaction}

Understanding engagement as multidimensional suggests that our measures should not just reflect learners' cognitive responsiveness but also social, affective, and behavioral aspects. In order to capture this, we are likely to require a range of indicators and sources, and these will differ according to context. In the specific examples of engagement in task-based interaction provided above, the main source was the transcripts of interaction, with some support provided through original sound files and exit questionnaires. Ideally, other sources would be used to complement these data. For example, Michell's (2012) study of learner engagement in activities in primary and secondary classrooms involved EAL learners, and it exemplifies how analysis of video recordings of classroom interaction can produce a wider range of indicators of engagement than transcripts alone. These include both verbal and nonverbal behaviors such as students' gestures, speech, and action within a lesson. Michell identified animated talk, laughing, exclamation, mounting excitement, collective affect bursts, waves of excitement, raised volume, bilingual comments, self-commentary, and nonverbal expressions as "affect displays" (pp. 412-414), which we would describe as indicators of emotional engagement. He was also able to identify indicators of engagement in students' "embodied dispositions," such as leaning forward and moving closer to the focus of the task (Michell, 2012, pp. 412-414). Data-driven measures of engagement such as this (as opposed to a list of predetermined indicators) are likely to provide the necessary flexibility to shape operationalization of engagement to the particular context of the research study in task-based research in classrooms. The use of motivation questionnaires (e.g., Kormos \& Csizér, 2014) and introspective interviews, such as stimulated recall (e.g., Baralt et al., 2016), would also provide insights into learner perceptions. Use of time sampling (e.g., Park, Holloway, Arendtsz, Bempechat, \& Li, 2012) may best capture fluctuations in engagement. 
Each of the various methods of assessing engagement has strengths and limitations, which may make one method more useful for assessing one dimension rather than another. For example, Skinner et al. (2009) suggested that self-report or interview may be better than observation for assessing cognitive or emotional engagement, whereas observation may be better for assessing behavioral and social engagement. Some measures may also be more suitable for particular groups of participants-self-report surveys may have limited reliability with younger students, for example. Following Fredricks and McColskey's (2012) review of methodologies, in which they discussed the advantages and disadvantages of various measures, the use of multiple methods is recommended, in order to gain a full understanding.

\section{CONCLUSIONS}

Task-based language researchers and teachers have intuitively recognized the importance of engagement to learning for some time. This article has drawn on recent theory and research to more explicitly define what we mean by engagement in tasks in the context of language learning, and to explore some of the ways it could be measured for classroom interaction. Following work in educational psychology, we have identified engagement in this context as a multidimensional construct, arguing that behavioral, cognitive, social, and emotional dimensions operate interdependently and mutually influence one another. In conclusion, we suggest two main implications and corresponding challenges, and we pose three questions arising from our review to be explored in future research.

\section{Implications}

First, we've suggested that engagement looks different according to context. Engagement must be operationalized by the researcher, with consideration of contextual factors such as the setting, the task, and the participants. While the definitions provided here are a starting point, the research context will necessitate more detailed and explicit definitions. Specifically, engagement should be operationalized based on a theoretical framework of L2 acquisition, with attention to the aspects that should be foregrounded in the particular context of the study.

Second, recognizing engagement as multidimensional means that our research, as well as our theoretical understanding of engagement in language learning, could benefit from exploring its multidimensionality in the language learning context. The interacting and overlapping processes of social, emotional, cognitive, and behavioral engagement, and their relation to learning, need to be explored specific to this context.

\section{Challenges}

The multidimensional, overlapping nature of the construct may present challenges for quantitative studies in particular. It may mean, for example, that analysis will 
involve combining measures across dimensions, rather than keeping them as separate. Mixed-method designs may be of assistance here, to allow both aggregated data on engagement as a whole to be presented and analyzed, as well as qualitative analysis of the particular contributions and interactions of the various dimensions of engagement. An example of this from education is the Effective Pre-School and Primary Education project, which involved case studies, psychometric data, observation, and interviews to build a powerful picture of preschool education and its effects (Sylva, Melhuish, Sammons, Siraj-Blatchford, \& Taggart, 2010).

Given the role of context in defining how engagement is described and measured, as the body of research investigating engagement in task-based language teaching grows, another challenge will be to draw disparate research studies together to provide an overarching picture of engagement and its influence on learning in language classrooms. As well as the individual descriptive and analytical studies of engagement in language classrooms that are starting to appear, syntheses of research and theoretical papers will be needed. This will allow us to develop a theoretical framework of the role of engagement in language learning, which may help both in framing future research and guiding teaching decisions around issues such as task selection, teaching methodologies, and responses to student disengagement.

\section{Questions for Future Research}

1. What are the processes by which engagement and language learning are linked? Building on existing work both in educational psychology and in L2 acquisition, theoretical models of the relationship between engagement and learning in language classrooms need to be more fully developed and tested by research.

2. How do these processes vary in different contexts? As argued earlier, how engagement manifests itself and how the different dimensions interrelate with one another will vary in each context for differing age groups of students, in varying curricular contexts, and for different kinds of tasks. Studying these relationships within a particular curricular context, such as task-based language learning, is not only important for illuminating the processes involved there, but also for mapping the processes across age groups. This will help to provide a developmental picture of engagement, across a range of tasks, which may help teachers with instructional design decisions. For example, it would be helpful to explore whether, how, and why engagement manifests differently in individual, small-group, and whole-class activities, as well as implications of this for language learning and teaching.

3. How are the dimensions of cognitive, social, emotional, and behavioral engagement evident in various learning situations? How do the dimensions interact to influence learning? While engagement is a single, multidimensional construct, various dimensions come to the fore in particular situations. How different dimensions link with learning may be investigated, and how they relate to one another is also an important question for study. Where multiple dimensions are active at the same time, they can either support or compete with one another. These interactions are worth studying to gain a clearer picture of how engagement works 
and, in particular, how it influences learning. This question may require multiple studies of engagement in multiple contexts to gain a full answer.

Engagement is a construct with enormous potential for student learning. Given its complexity, and the intricacy of the processes involved in linking it to learning, careful thought must be given to its definition and positioning in a research study. If we can develop a clear, well-theorized understanding of engagement in taskbased language learning, we are in a much better position to identify effective strategies for teachers and learners to maximize engagement and thus learning in the language classroom.

\section{ACKNOWLEDGMENT}

Our interest in engagement was first sparked when working on a study of child dyadic task-based interaction together with Rhonda Oliver. We are grateful for Rhonda's valuable input on this article. We also thank anonymous reviewers for their helpful feedback. Any shortcomings are our own.

\section{NOTE}

1. Pseudonyms are used for all studies reported.

\section{REFERENCES}

Adolph, K. E., \& Berger, S. E. (2011). Physical and motor development. In M. H. Borstein \& M. E. Lamb (Eds.), Developmental science: An advanced textbook (6th ed., pp. 241-302). Hillsdale, NJ: Erlbaum.

Ainley, M. (2012). Students' interest and engagement in classroom activities. In S. L. Christenson, A. L. Reschly, \& C. Wylie (Eds.), Handbook of research on student engagement (pp. 283-302). New York, NY: Springer.

Anderman, E. M., \& Patrick, H. (2012). Achievement goal theory, conceptualization of ability/intelligence, and classroom climate. In S. L. Christenson, A. L. Reschly, \& C. Wylie (Eds.), Handbook of research on student engagement (pp. 173-192). New York, NY: Springer.

Anderson, L. W. (1975). Student involvement in learning and school achievement. California Journal of Educational Research, 26(2), 53-62.

Baars, B. (1997). In the theatre of consciousness: Global workspace theory, a rigorous scientific theory of consciousness. Journal of Consciousness Studies, 4(4), 292-309.

Baralt, M., Gurzynski-Weiss, L., \& Kim, Y. (2016). Engagement with language: How examining learners' affective and social engagement explains successful learner-generated attention to form. In M. Sato \& S. Ballinger (Eds.), Peer interaction and second language learning. Pedagogical potential and research agenda (pp. 209-240). Amsterdam, The Netherlands: John Benjamins.

Barnes, D. (2008). Exploratory talk for learning. In N. Mercer \& S. Hodgkinson, Exploring talk in school (pp. 1-16). London, UK: Sage.

Barnes, D., \& Todd, F. (1995) Communication and learning revisited: Making meaning through talk. Portsmouth, NH: Boynton/Cook.

Bygate, M., \& Samuda, V. (2009). Creating pressure in task pedagogy: The joint roles of field, purpose, and engagement within the interaction approach. In A. Mackey \& C. Polio (Eds.), Multiple perspectives on interaction: Second language research in honour of Susan M. Gass (pp. 90-116).New York, NY: Taylor and Francis/Routledge.

Christenson, S., Reschly, A., \& Wylie, C. (2012). Handbook of research on student engagement. New York, NY: Springer.

Cleary, T., \& Zimmerman, B. (2012). A cyclical self-regulatory account of student engagement: Theoretical foundations and applications. In S. L. Christenson, A. L. Reschly, \& C. Wylie (Eds.), Handbook of research on student engagement (pp. 237-258). New York, NY: Springer. 
Csikszentmihalyi, M. (1990). Flow. New York, NY: Harper \& Row.

Damon, W., \& Phelps, E. (1989). Critical distinctions among three approaches to peer education. International Journal of Educational Research, 58, 9-19.

Darr, C. W. (2012). Measuring student engagement: The development of a scale for formative use. In S. L. Christenson, A. L. Reschly, \& C. Wylie (Eds.), Handbook of research on student engagement (pp. 707-724). New York, NY: Springer.

Deci, E. L., \& Ryan, R. M. (1985). Intrinsic motivation and self-determination in human behavior. New York, NY: Plenum.

Dobao, A. F. (2016). Peer interaction and learning: A focus on the silent learner. In M. Sato \& S. Ballinger (Eds.), Peer interaction and second language learning. Pedagogical potential and research agenda. (pp. 33-62). Amsterdam, The Netherlands: John Benjamins.

Dörnyei, Z., \& Kormos, J. (2000). The role of individual and social variables in oral task performance. Language Teaching Research, 4, 275-300.

Early, M., \& Marshall, S. (2008). Adolescent ESL students' interpretation and appreciation of literary texts: A case study of multimodality. Canadian Modern Language Review/Revue Canadienne des Langues Vivantes, 64, 377-397.

Ellis, N. C. (2015). Implicit and explicit language learning: Their dynamic interface and complexity. In P. Rebuschat (Ed.), Implicit and explicit learning of languages (pp. 3-24). Amsterdam, The Netherlands: John Benjamins.

Ellis, R. (2009). Task-based language teaching: Sorting out the misunderstandings. International Journal of Applied Linguistics, 19(3), 221-246.

Finn, J. D. (1989). Withdrawing from school. Review of Educational Research, 59, 117-142.

Finn, J. D., \& Zimmer, K. S. (2012). Student engagement: What is it? Why does it matter? In S. L. Christenson, A. L. Reschly, \& C. Wylie (Eds.), Handbook of research on student engagement (pp. 97-132). New York, NY: Springer.

Fredricks, J., Blumenfeld, P., \& Paris, A. (2004). School engagement: Potential of the concept, state of evidence. Review of Educational Research, 74(1), 59-105.

Fredricks, J. A., \& McColskey, W. (2012). The measurement of student engagement: A comparative analysis of various methods and student self-report instruments. In S. L. Christenson, A. L. Reschly, \& C. Wylie (Eds.), Handbook of research on student engagement (pp. 763-782). New York, NY: Springer.

García Mayo, M. P., \& Azkarai, A. (2016). EFL task-based interaction: Does task modality impact on language-related episodes? In M. Sato \& S. Ballinger (Eds.), Peer interaction and second language learning. Pedagogical potential and research agenda (pp. 241-266). Amsterdam, The Netherlands: John Benjamins.

Gass, S. (2003). Input and interaction. In C. Doughty \& M. Long (Eds.), The handbook of second language acquisition (pp. 224-255). Malden, MA: Blackwell.

Gass, S. M., \& Mackey, A. (2014). Stimulated recall methodology in second language research. Mahwah, NJ: Erlbaum.

Geeslin, K., \& Long, Y. M. (2014). Sociolinguistics and second language acquisition: learning to use language in context. New York, NY: Routledge.

Gettinger, M., \& Ball, C. (2007). Best practices in increasing academic engaged time. In A. Thomas \& J. Grimes (Eds.), Best practices in school psychology (Vol. 5) (pp. 1043-1075). Bethesda, MD: National Association of School Psychologists.

Gettinger, M., \& Walter, M. J. (2012). Classroom strategies to enhance academic engaged time. In S. L. Christenson, A. L. Reschly, \& C. Wylie (Eds.), Handbook of research on student engagement (pp. 653-673). New York, NY: Springer.

Gibbons, P. (1991). Learning to learn in a second language. Sydney, Australia: Primary English Teaching Association.

Guthrie, J. T., Wigfield, A., \& You, W. (2012). Instructional contexts for engagement and achievement in reading. In S. L. Christenson, A. L. Reschly, \& C. Wylie (Eds.), Handbook of research on student engagement (pp. 601-634). New York, NY: Springer.

Hartup, W. W. (1992). Having friends, making friends, and keeping friends: Relationships as educational contexts. ERIC digest (ED 345854). Urbana, IL: ERIC Clearinghouse on Elementary and Early Childhood Education. Retrieved from http://files.eric.ed.gov/fulltext/ED345854.pdf

Helme, S., \& Clarke, D. (2001). Identifying cognitive engagement in the mathematics classroom. Mathematics Education Research Journal, 13(2), 133-153.

Janosz, M. (2012). Part IV Commentary: Outcomes of engagement and engagement as an outcome: Some consensus, divergences, and unanswered questions. In S. L. Christenson, A. L. Reschly, \& 
C. Wylie (Eds.), Handbook of research on student engagement (pp. 695-703). New York, NY: Springer.

Kormos, J., \& Csizér, K. (2014). Age-related differences in the motivation of learning English as a foreign language: Attitudes, selves and motivated learning behaviour. Language Learning, 58(2), 327-355.

Kowal, M., \& Swain, M. (1994). Using collaborative language production tasks to promote students' language awareness. Language Awareness, 3(2), 73-93.

Lam, S., Wong, B. P. H., Yang, H., \& Liu, Y. (2012). Understanding student engagement in a contextual model. In S. L. Christenson, A. L. Reschly, \& C. Wylie (Eds.), Handbook of research on student engagement (pp. 403-420). New York, NY: Springer.

Lambert, C., \& Philp, J. (2015). Learner-generated content and learner engagement in L2 performance. Symposium paper presented at the Sixth International Task-Based Language Teaching Conference, Leuven, Belgium. Retrieved from https://www.academia.edu/20732979/_ 2015_Learner-Generated_Content_and_Learner_Engagement_in_L2_Performance

Lantolf, J. (2012). Sociocultural theory: A dialectic approach to L2 research. In S. M. Gass \& A. Mackey (Eds.), The Routledge handbook of second language acquisition (pp. 57-72). London, UK: Routledge.

Larsen-Freeman, D. (2014). Complexity theory. In S. M. Gass \& A. Mackey (Eds.), The Routledge handbook of second language acquisition (pp. 73-88). Oxon, UK: Routledge.

Larsen-Freeman, D., \& Cameron, D. (2008). Complex systems and applied linguistics. Oxford, UK: Oxford University Press.

Lawson, M. A., \& Lawson, H. A. (2013). New conceptual frameworks for student engagement research, policy and practice. Review of Educational Research, 83(3), 432-479.

Leow, R. (2015). Explicit learning in the L2 classroom. A student centered approach. New York, NY: Routledge.

Long, M. (1996). The role of the linguistic environment in second language acquisition. In W. C. Ritchie \& T. K. Bhatia (Eds.), Handbook of second language acquisition (pp. 413-468). San Diego: Academic Press.

Mahatmya, D., Lohman, B. J., Matjasko, J. L., \& Feldman Farb, A. (2012). Engagement across developmental periods. In S. L. Christenson, A. L. Reschly, \& C. Wylie (Eds.), Handbook of research on student engagement (pp. 45-64). New York, NY: Springer.

Martin, A. J. (2012). Part II Commentary: Motivation and engagement: Conceptual, operational and empirical clarity. In S. L. Christenson, A. L. Reschly, \& C. Wylie (Eds.), Handbook of research on student engagement (pp. 303-314). New York, NY: Springer.

McGaugh, J. L. (2013). Making lasting memories: Remembering the significant. Proceedings of the National Academy of Sciences, USA, 110 (Suppl. 2), 10402-10407.

Mercer, N. (1995). The guided construction of knowledge: Talk amongst teachers and learners. Clevedon, UK: Multilingual Matters.

Mercer, N., \& Dawes, L. (2008). The value of exploratory talk. In N. Mercer \& S. Hodgkinson, Exploring talk in school (pp. 55-72). London, UK: Sage.

Mercer, S. (2011). Understanding learner agency as a complex dynamic system. System, 39(4), 427436.

Michell, M. (2012). Academic engagement and agency in multilingual middle year classrooms (Unpublished doctoral dissertation). University of Sydney, Australia.

Moranski, K., \& Toth, P. (2016). Small-group meta-analytic talk and Spanish L2 development. In M. Sato \& S. Ballinger (Eds.), Peer interaction and second language learning. Pedagogical potential and research agenda (pp. 291-319). Amsterdam, The Netherlands: John Benjamins.

O'Donnell, A. M. (2006). The role of peers and group learning. In P. Alexander \& P. Winne (Eds.), Handbook of educational psychology (2nd ed., pp. 781-802). Mahwah, NJ: Erlbaum.

Oliver, R., Philp, J., \& Mackey, A. (2008). Age, teacher guidance and the linguistic outcomes of task-based interaction. In J. Philp, R. Oliver, \& A. Mackey (Eds.), Child's play? Second language acquisition and the younger learner (pp. 131-147). Amsterdam, The Netherlands: John Benjamins.

Park, S., Holloway, S. D., Arendtsz, A., Bempechat, J., \& Li, J. (2012). What makes students engaged in learning? A time-use study of within- and between- individual predictors of emotional engagement in low-performing high schools. Journal of Youth Adolescence, 41, 390-401.

Pekrun, R., Goetz, T., Titz, W., \& Perry, R. P. (2002). Academic emotions in students' self-regulated learning and achievement: A program of quantitative and qualitative research. Educational Psychologist, 37, 91-106. 
Pekrun, R., \& Linnenbrink-Garcia, L. (2012). Academic emotions and student engagement. In S. L. Christenson, A. L. Reschly, \& C. Wylie (Eds.), Handbook of research on student engagement (pp. 259-282). New York, NY: Springer.

Philp, J., \& Duchesne, S. (2008). When the gate opens: The interaction between social and linguistic goals in child second language development. In J. Philp, R. Oliver, \& A. Mackey (Eds.), Child's play? Second language acquisition and the young learner, (pp. 83-104). Amsterdam, The Netherlands: John Benjamins.

Posner, M., \& Rothbart, M. (2000). Developing mechanisms of self-regulation. Development and Psychopathology, 12(3), 427-442.

Reeve, J. (2012). A self-determination theory perspective on student engagement. In S. L. Christenson, A. L. Reschly, \& C. Wylie (Eds.), Handbook of research on student engagement (pp. 149-172). New York, NY: Springer.

Reschly, A. L., \& Christenson, S. L. (2012). Jingle, jangle, and conceptual haziness: Evolution and future directions of the engagement construct. In S. L. Christenson, A. L. Reschly, \& C. Wylie (Eds.), Handbook of research on student engagement (pp. 30-19). New York, NY: Springer.

Robinson, P. (1995). Attention, memory and the noticing hypothesis. Language Learning, 45, 283-331.

Sato, M., \& Ballinger, S. (2012). Raising language awareness in peer interaction: A cross-context, cross-method examination. Language Awareness, 21(1-2), 157-179.

Schmidt, R. (2001). Attention. In P. Robinson (Ed.), Cognition and second language instruction (pp. 3-32). Cambridge, UK: Cambridge University Press.

Schumann, J. (1997). The neurobiology of affect in language. Language and Learning, 48 (Suppl. 1), XV-337.

Schunk, D., \& Miller, S. (2002). Self-efficacy and adolescents' motivation. In F. Pajares \& T. Urdan (Eds.), Academic motivation of adolescents (pp. 29-52). Greenwich, CT: Information Age.

Skinner, E. A., Kindermann, T. A., \& Furrer, C. (2009). A motivational perspective on engagement and disaffection: Conceptualization and assessment of children's behavioral and emotional participation in academic activities in the classroom. Educational and Psychological Measurement, 69, 493-525.

Skinner, E. A., \& Pitzer, J. R. (2012). Developmental dynamics of engagement, coping, and everyday resilience. In S. L. Christenson, A. L. Reschly, \& C. Wylie (Eds.), Handbook of research on student engagement (pp. 21-44). New York, NY: Springer.

Storch, N. (2002). Patterns of interaction in ESL pair work. Language Learning, 52(1), 119-158.

Storch, N. (2008). Metatalk in a pair work activity: Level of engagement and implications for language development. Language Awareness, 17, 95-114.

Svalberg, A. (2009). Engagement with language: Interrogating a construct. Language Awareness, 18(34), 242-258.

Svalberg, A. (2012). Thinking allowed: Language awareness in language learning and teaching: A research agenda. Language Teaching, 45(3), 376-388.

Swain, M. (2013). The inseparability of cognition and emotion in second language learning. Language Teaching, 46(2), 195-207.

Swain, M., \& Lapkin, S. (2001). Focus on form through collaborative dialogue: Exploring task effects. In M. Bygate, P. Skehan, \& M. Swain (Eds.), Researching pedagogic tasks: Second language learning, teaching and testing (pp. 99-118). London, UK: Longman.

Sylva, K., Melhuish, E, Sammons, P., Siraj-Blatchford, I., \& Taggart, B. (2010). Early childhood matters: Evidence from the Effective Pre-School and Primary Education project. Oxon, UK: Routledge.

Toth, P. D., Wagner, E., \& Moranski, K. (2013). "Co-constructing" explicit L2 knowledge with high school Spanish learners through guided induction. Applied Linguistics, 34(3), 255-278. doi:10.1093/applin/ams049

Webb, N. M. (2013). Information processing approaches to collaborative learning. In C. E. HmeloSilver, C. A. Chinn, C. K. K. Chan, \& A. M. O'Donnell (Eds.), The international handbook of collaborative learning (pp. 19-40). New York, NY: Routledge.

Weiss, P. R. (2000). Emotion and learning. Training and Development, 54(11), 44-48.

Yazzie-Mintz, E. (2009). Engaging the voices of students: A report on the 2007 \& 2008 high school survey of student engagement. Bloomington, IN: Center for Evaluation and Education Policy.

Yazzie-Mintz, E., \& McCormick, K. (2012). Finding the humanity in the data; Understanding, measuring and strengthening student engagement. In S. L. Christenson, A. L. Reschly, \& C. Wylie (Eds.), Handbook of research on student engagement (pp. 743-762). New York, NY: Springer. 